\title{
RIGHTS AND MODERN SLAVERY: THE OBLIGATIONS OF STATES AND CORPORATIONS IN RELATION TO FORCED LABOUR IN GLOBAL SUPPLY CHAINS
}

Rose Ireland*

\begin{abstract}
Despite slavery being criminalised globally, modern slavery is widespread, affecting nearly every country in the world. Forced labour within corporate global supply chains is a particularly elusive form of modern slavery that has seldom been addressed until recent years. The risk of forced labour occurring in global supply chains is exacerbated by the 'governance gap' in which multinational corporations operate. This article will critically analyse the application of an international soft law instrument established to address this gap - the United Nations Guiding Principles on Business and Human Rights ('UNGP') - to the issue of forced labour within corporate global supply chains. It will evaluate the potential of each of the three 'pillars' outlined in the UNGPs in combating forced labour and examine practical examples of efforts made by states and corporations to address forced labour that amount to implementation of the UNGPs, drawing on practice in the United States and the United Kingdom in particular. It will be concluded that the UNGPs are a valuable weapon in the fight against modern slavery, but that effective implementation will be challenging. A multi-pronged approach is required, mobilising state and corporate actors and incorporating both voluntary and mandatory measures that are mutually reinforcing.
\end{abstract}

\section{A. INTRODUCTION AND BACKGROUND}

\section{Introduction}

In recent decades, corporate power and transnational economic activity has increased alongside international trends towards globalisation, privatisation and deregulation. ${ }^{1}$ Today, corporate supply chains are no longer limited to firms and facilities based in one country. Instead, they are comprised of multiple contractor factories dispersed worldwide, ${ }^{2}$ with multinational corporations ('MNC') outsourcing production to developing countries in order to reduce operational costs. ${ }^{3}$ As the supply chains of MNCs have become more extensive, they have also become more complex and opaque. ${ }^{4}$ This is problematic not least because the influence and reach of MNCs means that they can affect virtually all human rights anywhere

\footnotetext{
* LLB Law 2014 (Bristol); LLM Human Rights Law 2016 (Edinburgh). I am grateful to Dr Kasey McCall for her supervision on the original version of this article as a dissertation at the University of Edinburgh.

${ }^{1}$ Aoife Nolan, 'Addressing Economic and Social Rights Violations by Non-state Actors through the Role of the State: A Comparison of Regional Approaches to the 'Obligation to Protect' (2009) 9(2) H R L Rev 225, 226.

${ }^{2}$ David J Doorey, 'The Transparent Supply Chain: from Resistance to Implementation at Nike and LeviStrauss' (2011) 103(4) J Business Ethics 587, 591.

${ }^{3}$ Justine Nolan, 'The Corporate Responsibility to Respect Human Rights: Soft Law or Not Law?' in Surya Deva and David Bilchitz (eds), Human Rights Obligations of Business: Beyond the Corporate Responsibility to Respect? (Cambridge University Press 2013) 138, 152.

${ }^{4}$ Sophia Eckert, 'The Business Transparency on Trafficking and Slavery Act: Fighting Forced Labor in Complex Global Supply Chains’ (2013) 12(2) J Intl Business L 383, 386.
} 
in the world. ${ }^{5}$ Moreover, while MNC activity has rapidly evolved, the legal framework governing MNCs has trailed behind, creating a 'governance gap' in which global supply chains operate. ${ }^{6}$ A number of soft law instruments have emerged to address this gap, ${ }^{7}$ the most recent and authoritative of which is the 2011 United Nations Guiding Principles on Business and Human Rights ('UNGPs'), ${ }^{8}$ which operationalise the 2008 Protect, Respect and Remedy Framework. ${ }^{9}$

The 'governance gap', coupled with the trends that have facilitated the expansion of corporate power, have also facilitated the growth of modern slavery in the form of forced labour in economic activities. ${ }^{10}$ Forced labour within corporate global supply chains is a particularly elusive form of modern slavery that has seldom been addressed until recent years. ${ }^{11}$ The right to be free from slavery is a fundamental human right enshrined in numerous international instruments, ${ }^{12}$ and the prohibition of slavery is considered to be jus cogens, ${ }^{13}$ erga omnes, ${ }^{14}$ and a norm of customary international law. ${ }^{15}$ Modern slavery can also entail egregious violations of a broad catalogue of multiple human rights ${ }^{16}$ and have destructive social, economic and political consequences. ${ }^{17}$ Thus, forced labour in corporate supply chains is a major human rights issue.

This article will critically analyse the application of the three pillars in the UNGPs to the issue of forced labour within corporate global supply chains. Section B will evaluate the

\footnotetext{
${ }^{5}$ UNHRC, 'Report of the Special Representative of the Secretary-General on the Issue of Human Rights and Transnational Corporations and Other Business Enterprises' (7 April 2008) UN Doc A/HRC/8/5 paras 2, 6.

${ }^{6}$ ibid paras $3,13,104$.

${ }^{7}$ Mette Andersen and Tage Skjoett-Larsen, 'Corporate Social Responsibility in Global Supply Chains' (2009) 14(2) Supply Chain Management: An Intl J 75, 82.

${ }^{8}$ United Nations, United Nations Guiding Principles on Business and Human Rights: Implementing the United Nations 'Protect, Respect and Remedy' Framework (United Nations 2011) (UNGPs).

${ }^{9}$ UNHRC (n 5).

${ }^{10}$ Benjamin Thomas Greer and Jeffrey Purvis, 'Corporate Supply Chain Transparency: California's Seminal Attempt to Discourage Forced Labour' (2016) 20(1) Intl J Human Rights 55, 60.

${ }^{11}$ Caroline Robinson, 'Claiming Space for Labour Rights within the United Kingdom Modern Slavery Crusade' (2015) 5 Anti-Trafficking Rev 129, 131.

${ }^{12}$ Eg Universal Declaration of Human Rights (adopted 10 December 1948) UNGA Res 217 A(III) (UDHR) art 4; International Covenant on Civil and Political Rights (adopted 16 December 1966, entered into force 23 March 1976) 999 UNTS 171 (ICCPR), art 8; Convention for the Protection of Human Rights and Fundamental Freedoms (European Convention on Human Rights, as amended) [1950] (ECHR) art 4; Charter of Fundamental Rights of the European Union [2012] OJ C 326/02, art 5; American Convention on Human Rights (San José, Costa Rica) (22 November 1969) OAS Treaty Series No 36 (ACHR), art 6.

${ }^{13}$ Vienna Convention on the Law of Treaties (adopted 23 May 1969, entered into force 27 January 1980) 1155 UNTS 331, art 53; International Law Commission, 'Draft Articles on the Law of Treaties with commentaries' Yearbook of the International Law Commission 1966, vol. II (1966) Un Doc A/CN.4/SER. A/1966/Add.1 248.

${ }^{14}$ Barcelona Traction, Light and Power Company, Limited (Belgium v Spain) [1970] ICJ Rep 13, [34].

${ }^{15}$ Prosecutor v Kunarac, Kovac and Vukovic (2001) ICTY, IT-96-23-T and IT-96-23/1-T [520].

${ }^{16}$ Eg ICCPR arts 7, 9; International Covenant on Economic, Social and Cultural Rights (adopted 16 December 1966, entered into force 3 January 1976) 993 UNTS 3 (ICESCR) art 7.

${ }^{17}$ United Nations Office on Drugs and Crime, An Introduction to Human Trafficking: Vulnerability, Impact and Action (United Nations, 2008) 4.
} 
potential of each of the pillars in combating forced labour. Section $\mathrm{C}$ will examine practical examples of efforts made to address forced labour that amount to implementation of the UNGPs. It will draw from practice in the United States ('US') and the United Kingdom ('UK') in particular, since these governments are amongst those taking the most action against slavery and have numerous MNCs incorporated or operating within them. ${ }^{18}$ It will be concluded that the UNGPs are a valuable weapon in the fight against modern slavery, but that effective implementation will be challenging. A multi-pronged approach is required, mobilising state and corporate actors and incorporating both voluntary and mandatory measures that are mutually reinforcing. ${ }^{19}$

\section{Background}

a) Modern slavery

Despite slavery being criminalised globally, ${ }^{20}$ modern slavery - 'a complex manifestation of the global economy, organized crime and human rights violations' - is widespread, affecting nearly every country in the world. ${ }^{21}$ There are numerous international instruments that address slavery ${ }^{22}$ and modern slavery. ${ }^{23}$ Modern slavery is a contentious term and the alternative terminology of 'trafficking in persons' is commonly invoked in international instruments. ${ }^{24}$ In essence, both modern slavery and 'trafficking in persons' are umbrella terms for the disparate, but related, offences of slavery, forced labour, domestic servitude and human trafficking. ${ }^{25}$ Modern slavery is vast in scope, taking varied forms that serve a range of exploitative purposes. $^{26}$

\footnotetext{
${ }^{18}$ Global Slavery Index, The Global Slavery Index 2016 (Global Slavery Index, 2016) 5.

${ }^{19}$ Greer and Purvis (n 10) 57.

${ }^{20}$ International Labour Organization, ILO 2012 Global Estimate of Forced Labour: Executive Summary (International Labour Organization, 2012) 4.

${ }^{21}$ United Nations Office on Drugs and Crime (UNODC), Global Report on Trafficking in Persons 2014 (United Nations 2014) 1.

${ }^{22}$ Eg Declaration Relative to the Universal Abolition of the Slave Trade (signed 8 February 1815) 63 CTS 473; Slavery Convention (adopted 25 September 1926, entered into force 9 March 1927) 60 LNTS 253 (Slavery Convention).

${ }^{23}$ Eg Convention for the Suppression of the Traffic in Persons and the Exploitation of the Prostitution of Others (adopted 2 December 1949, entered into force 25 July 1951) 96 UNTS 271; Protocol to Prevent, Suppress and Punish Trafficking in Persons, Especially Women and Children, Supplementing the United Nations Convention against Transnational Organized Crime (adopted 15 November 2000) (Trafficking Protocol); UN General Assembly, Convention against Transnational Organized Crime: Resolution (adopted 10 November 2000) A/RES/55/25; International Labour Organization, Forced Labour Convention (adopted 28 June 1930, entered into force 1 May 1931) ILO No. 29; International Labour Organization, Abolition of Forced Labour Convention (adopted 25 June 1957, entered into force 17 January 1959) (ILO No. 105); International Labour Organization, ILO Declaration on Fundamental Principles and Rights at Work (adopted 18 June 1998).

${ }^{24}$ Jason Haynes, ‘The Modern Slavery Act (2015): A Legislative Commentary' (2016) 37(1) Stat L R 33, 35.

${ }^{25}$ ibid. See Trafficking Protocol art 3(a).

${ }^{26}$ ibid.
} 
The ILO predicts that out of the 20.9 million victims of modern slavery globally, 14.2 million are victims of forced labour. ${ }^{27}$ Forced labour 'refers to situations in which persons are coerced to work through the use of violence or intimidation, or by more subtle means, ${ }^{28}$ for the purpose of economic exploitation and production. ${ }^{29}$ To amount to modern slavery working conditions must be characterised by coercion, control, restrictions on liberty and severe violations to human rights and dignity. ${ }^{30}$ It can occur at any stage in the supply chain and affects virtually all industries, including but not limited to agriculture, aquaculture, construction and fashion. ${ }^{31}$

\section{The protect, respect and remedy framework and the UNGPS}

The Protect, Respect and Remedy Framework was established in $2008 .{ }^{32}$ It rests on three 'differentiated but complementary' pillars: the State duty to protect against human rights abuses by corporations, the corporate responsibility to respect human rights, and the need for greater access to effective remedy for victims. ${ }^{33}$ The 2011 UNGPs retain the pillars and introduce a number of principles designed to operationalise - 'that is, to provide concrete and practical recommendations for ... implementation' - the Framework, applicable to all states and business enterprises. ${ }^{34}$ Each pillar is underpinned by differing legal and policy bases, but they form a 'coherent whole'. ${ }^{35}$ Both the UNGPs and the Framework were formulated by the Special Representative on the Issue of Human Rights and Transnational Corporations and Other Business Enterprises, John Ruggie, and were unanimously endorsed by the United Nations Human Rights Council. ${ }^{36}$ The UNGPs are soft law: they clarify and elaborate upon the pre-existing responsibilities of states and corporations and do not change any existing legal obligations or create new ones. ${ }^{37}$ Ruggie argues that since individual actions by states and corporations are limited in what they can achieve, concerted efforts are required by states

\footnotetext{
${ }^{27} \operatorname{ILO}(\mathrm{n} 20) 1$.

${ }^{28}$ International Labour Organisation, 'The Meanings of Forced Labour' (International Labour Organization 2014) <www.ilo.org/global/topics/forced-labour/news/WCMS_237569/lang--en/index.htm\%202012> accessed 13 July 2017.

${ }^{29}$ Stefan Gold, Alexander Trautrims and Zoe Trodd, 'Modern Slavery Challenges to Supply Chain Management' (2015) 20(5) Supply Chain Management: An Intl J 485, 487.

${ }^{30}$ Anna Shavers, 'Human Trafficking, The Rule of Law, and Corporate Social Responsibility' (2012) 9(1) South Carolina J Intl L Business 39, 76.

${ }^{31} \operatorname{ILO}(\mathrm{n} 20) 1$.

${ }^{32}$ UNHRC (n 5).

33 ibid para 9.

${ }^{34}$ UNHRC 'Report of the Special Representative of the Secretary-General on the Issue of Human Rights and Transnational Corporations and other Business Enterprises' (21 March 2011) UN Doc A/HRC/17/31 para 9.

${ }^{35}$ UNGPs (n 8) 1.

${ }^{36}$ UNHRC 'Human Rights and Transnational Corporations and Other Business Enterprises' (6 July 2011) A/HRC/RES/17/4; UNHRC 'Mandate of the Special Representative of the Secretary-General on the Issue of Human Rights and Transnational Corporations and Other Business Enterprises' (18 June 2008) A/HRC/RES/8/7

${ }^{37}$ UNGPs (n 8) 1.
} 
and corporations. ${ }^{38}$ The UNGPs aim to bridge the governance gap by providing, for the first time, a specific focal point from which actors' expectations can converge and develop. ${ }^{39}$ The UNGPs are widely supported; this may partially be due to the widespread consultations Ruggie conducted with stakeholders in developing the UNGPs. ${ }^{40}$

\section{B. THE PILLARS}

This section will outline each pillar and assess their potential, both individually and collectively, in the context of their application to forced labour. To a certain extent, the pillars resemble the '3Ps' approach to tackling modern slavery advanced by the United Nations: protecting victims, preventing modern slavery, and prosecuting perpetrators. ${ }^{41}$

\section{State duty to protect}

According to the UNGPs, states have a duty to protect against human rights abuses by corporations within their territory or jurisdiction. ${ }^{42}$ This duty is grounded in recognition of the existing legal obligations to which states are subject under international human rights law. ${ }^{43}$ All states have ratified at least one of the major international human rights law treaties. ${ }^{44}$ Under these treaties, states have both positive obligations to protect against human rights abuses by non-state actors and negative obligations to refrain from interfering with the enjoyment of human rights, ${ }^{45}$ duties to respect, protect and fulfil human rights. ${ }^{46}$ The European Court of Human Rights has affirmed that the right to be free from slavery imposes a duty on states to regulate entities that engage in slavery, including corporations. ${ }^{47}$ This is important since forced labour is predominantly perpetrated by private, not state, actors. Thus, the 'protect' pillar encompasses forced labour.

\footnotetext{
${ }^{38}$ UNHRC (n 5) para 17.

${ }^{39}$ UNHRC (n 34) para 5.

${ }^{40}$ Robert McCorquodale, 'Corporate Social Responsibility and International Human Rights Law' (2009) 87(2) J Business Ethics 385, 385-386.

41 United Nations Office on Drugs and Crime, 'Human Trafficking' (UNODC, 2017) $<$ www.unodc.org/unodc/en/human-trafficking/what-is-human-trafficking.html?ref=menuside $>$ accessed 13 July 2017.

${ }^{42}$ UNGPs (n 8) 3

43 ibid 1.

${ }^{44}$ McCorquodale (n 40) 386.

${ }^{45}$ Human Rights Committee 'General Comment No. 31: Nature of the General Legal Obligation Imposed on States Parties to the Covenant' (26 May 2004) CCPR/C/21/Rev.1/Add.13. para 6; Case of $X$ and $Y v$ The Netherlands App no 8978/80 (ECHR, 26 March 1985) [23]; Case of Ximenes-Lopes v Brazil, Inter-American Court on Human Rights Series C No 149 (4 July 2006) [85].

${ }^{46}$ See Committee on Economic, Social and Cultural Rights 'General Comment 12: The Right to Adequate Food (art11)' (12 May 1999) E/C.12/1999/5 para 15.

${ }^{47}$ Case of Siliadin v France App no 73316/01 (ECHR, 26 July 2005) [89], [112]; Case of Rantsev v Cyprus and Russia App no 25965/04 (ECHR, 7 January 2010) [283]-[289].
} 
Corporate abuses are not generally directly attributable to states under international law. ${ }^{48}$ Where forced labour occurs within corporate supply chains, the state is not directly responsible for the abuse itself, but might be responsible for enabling the corporation to act as it did by failing to take reasonable measures to prevent, investigate and punish forced labour and provide redress for victims. ${ }^{49}$ The duty to protect is a standard of conduct, not result. ${ }^{50}$ In human rights discourse, this standard is known as due diligence, ${ }^{51}$ but this terminology is not adopted in the UNGPs in relation to the state duty. The duty is neither absolute nor unlimited and the actions required to satisfy the standard will vary according to a number of factors, giving states discretion in deciding what measures to adopt. ${ }^{52}$ Appropriate steps for forced labour would include, at a minimum, the enactment and enforcement of a regulatory regime addressing corporate complicity in forced labour, punishment for non-compliance, and increasing remedies for victims. ${ }^{53}$ This is supported by international treaties addressing modern slavery which require, inter alia, that all forms of modern slavery are criminalised. ${ }^{54}$

In formulating policies addressing corporate-related human rights harms, the UNGPs emphasise the need for states to strive for policy coherence: ensuring that other laws 'do not constrain but enable business respect for human rights. ${ }^{55}$ States often segregate or heavily discount business and human rights policies from other policy domains that influence business activity. ${ }^{56}$ A common criticism of state efforts to tackle forced labour is that they are too narrow and fail to rectify the broader socioeconomic conditions that cause it in the first place. ${ }^{57}$ For example, low protection for migrants and low-skilled workers make these groups more vulnerable and can undermine policy efforts to tackle forced labour. ${ }^{58}$ Modern slavery is a multi-dimensional issue involving a range of policy realms and legal fields, such as, migration, employment and company law. Coherence in state policy is critical to combating forced labour.

\footnotetext{
${ }^{48}$ Anne T Gallagher, The International Law of Human Trafficking (Cambridge University Press 2010) 235-236.

${ }^{49}$ UNGPs (n 8) 3; See HRC (n 45) para 8; Olivier De Schutter, International Human Rights Law: Cases, Materials, Commentary (2nd edn, Cambridge University Press 2014) 479.

${ }^{50}$ John H Knox, 'Horizontal Human Rights Law' (2008) 102(1) AJIL 22.

${ }^{51}$ Eg Case of Velásquez-Rodríguez v Honduras, Inter-American Court of Human Rights, Series C No 4 (29 July 1988) [172].

${ }^{52}$ Knox (n 50) 23; Case of Osman v the United Kingdom App no 23452/94 (ECtHR, 28 Oct 1998) [116].

${ }^{53}$ Siliadin (n 47) [89], [112]; Rantsev (n 47) [283]-[289].

${ }^{54}$ Trafficking Protocol art 5.

${ }^{55}$ UNGPs (n 8) 4; UNHRC (n 5) para 33.

${ }^{56}$ UNHRC (n 5) para 22.

${ }^{57}$ Stephen J New, 'Modern Slavery and the Supply Chain: the Limits of Corporate Social Responsibility?' (2015) 20(6) Supply Chain Management: An Intl J 697, 701.

${ }^{58}$ Robinson (n 11) 133.
} 
To fulfil their duty to protect, states must encourage corporate nationals to respect human rights 'throughout their operations, ${ }^{59}$ both within and outside their territories. ${ }^{60}$ The potential extraterritorial reach of the state duty to protect is important in addressing forced labour due to its transnational nature. The UNGPs emphasise the importance of home state (where MNCs are incorporated) regulation for human rights protection. ${ }^{61}$ This is largely because host states (where MNCs' suppliers are based) in developing countries often lack the resources and institutional capacity of home states. ${ }^{62}$ Host states may also be incentivised to relax regulatory standards to attract foreign investment and increase revenues by being less burdensome for MNCs. ${ }^{63}$ Conversely, host states may be prevented from strengthening human rights protections due to bilateral investment agreements. ${ }^{64}$ This contributes to the 'governance gap' which exacerbates the risk of forced labour. The UNGPs highlight that home states could help bridge that gap.

Home states in developed countries are well-positioned to apply pressure on MNCs within their jurisdiction to tackle forced labour. ${ }^{65}$ There is no consensus, however, on whether the international human rights law obligations of states extend to the extraterritorial activities of corporate nationals, and if so, whether and in what circumstances home states can exercise and enforce their jurisdiction abroad. ${ }^{66}$ These debates are outside the scope of this article. Suffice to say the UNGPs assert that while it is unclear whether states are legally obliged to regulate the extraterritorial activities of corporate nationals, they are not prohibited from doing so provided they have a 'recognised jurisdictional basis ${ }^{67}$ Even if jurisdiction can be established, however, home states face a number of practical hurdles in enforcing their

\footnotetext{
${ }^{59}$ UNGPs (n 8) 13.

60 Robert McCorquodale and Penelope Simons, 'Responsibility Beyond Borders: State Responsibility for Extraterritorial Violations by Corporations of International Human Rights Law' (2007) 70(4) MLR 598, 599; Oxfam, Business and Human Rights: An Oxfam Perspective on the UN Guiding Principles (Oxfam, 2013) $<$ www.oxfam.org/sites/www.oxfam.org/files/tb-business-human-rights-oxfam-perspective-un-guidingprinciples-130613-en.pdf $>$ accessed 13 July 2017, 6.

${ }^{61}$ Andreas Rühmkorf, Corporate Social Responsibility, Private Law and Global Supply Chains (Edward Elgar Publishing 2015) 232.

${ }^{62}$ UNHRC (n 5) para 14; Katerina Peterkova Mitkidis, 'Sustainability Clauses in International Supply Chain Contracts: Regulation, Enforceability and Effects of Ethical Requirements' (2014) 1 Nordic J Commercial L 1, 3.

${ }^{63}$ Nicholas Connolly, 'Corporate Social Responsibility: A Duplicitous Distraction?' (2012) 16(8) Intl J Human Rights 1228, 1229.

${ }^{64}$ UNHRC (n 5) para 34; Steven R Ratner, 'Corporations and Human Rights: A Theory of Legal Responsibility' (2001) 111(3) Yale L J 443, 535.

${ }^{65}$ McCorquodale and Simons (n 60) 600.

${ }^{66}$ UNHRC (n 5) para 19; Louise Vytopil, 'Contractual Control and Labour-Related CSR Norms in the Supply Chain: Dutch Best Practices’ (2012) 8(1) Utrecht L Rev 155, 156.

${ }^{67}$ UNGPs (n 8) 3-4.
} 
jurisdiction in another state's territory. ${ }^{68}$ These hurdles are exacerbated by theories of corporate law which separate top-tier corporations' liability from those of their supply chain firms. Thus, the capability of home states to regulate modern slavery occurring within the supply chains of its corporate nationals has some promise but is also inherently limited. This affirms Ruggie's assertion that to meet the human rights challenges posed by MNCs, 'the active participation of business' is also required. ${ }^{69}$

\section{Corporate responsibility to respect}

The UNGPs state that corporations have a responsibility to respect human rights. ${ }^{70}$ This responsibility applies to all corporations in respect of all 'internationally recognized human rights'. ${ }^{71}$ Such rights are violated by forced labour, thus this pillar encompasses forced labour. The terminology 'responsibility' and 'duty' distinguishes the nature of corporate and state obligations. ${ }^{72}$ Although the content of this pillar is defined by reference to legal instruments, unlike the state duty to protect this pillar is not grounded in law. Rather, it articulates the 'baseline expectation for all companies in all situations' as part of a company's 'social licence to operate' ${ }^{73}$ The UNGPs simply express a norm which was already emerging, partially as a result of the proliferation of voluntary international and private instruments asserting that businesses should adhere to human rights standards. ${ }^{74}$

The decision to ground this pillar in social expectations is consistent with the traditional view that international law imposes duties only on states, not on private actors. ${ }^{75}$ This approach has been widely endorsed by both states and corporations. ${ }^{76}$ Some scholars, however, criticise it for being too 'soft', arguing that corporations should be subject to binding international human rights law. ${ }^{77}$ These arguments are outside the scope of this article. As things stand, corporations are not duty-bearers under international human rights law and the UNGPs do not seek to change that position. ${ }^{78}$ Thus, international law does not

\footnotetext{
${ }^{68}$ McCorquodale (n 40) 389.

${ }^{69}$ UNHRC (n 5) para 50.

${ }^{70}$ UNGPs (n 8) 13.

${ }^{71}$ ibid.

${ }^{72}$ Björn Fasterling and Geert Demuijnck, 'Human Rights in the Void? Due Diligence in the UN Guiding Principles on Business and Human Rights' (2013) 116(4) J Business Ethics 799, 800.

${ }^{73}$ UNHRC (n 5) paras 24, 54; UNGPs (n 8) 13.

${ }^{74}$ Erika R George and Scarlet R Smith, 'In Good Company: How Corporate Social Responsibility Can Protect Rights and Aid Efforts to End Child Sex Trafficking and Modern Slavery' (2013) 46(1) New York University J Intl L Politics 55, 82.

${ }^{75}$ Nolan (n 3) 146.

${ }^{76}$ Connolly (n 63) 1231.

${ }^{77}$ Wesley Cragg, 'Human Rights and Business Ethics: Fashioning a New Social Contract' (2000) 27(1) J Business Ethics 205, 213; Nolan (n 3) 139.

${ }^{78}$ McCorquodale (n 40) 391.
} 
impose a direct duty on corporations not to engage in slavery. ${ }^{79}$ This forms another aspect of the 'governance gap': despite their international presence, the legal responsibilities of MNCs in relation to human rights are defined by national law. ${ }^{80}$ The corporate responsibility to respect, therefore, is closely linked to the state duty to protect since to fulfil their own international obligations, states must enact laws at the domestic level which enforce corporate responsibility for human rights abuses. ${ }^{81}$

The corporate responsibility to respect is not merely a passive responsibility of noninterference but encompasses avoiding complicity in abuses committed by other actors. ${ }^{82}$ It entails three modes of corporate responsibility: ${ }^{83}$ first, for directly causing human rights abuses through its own activities; ${ }^{84}$ second, for contributing to human rights abuses committed by other actors; ${ }^{85}$ and third, for having direct links to adverse human rights impacts, including through its supply chain regardless of whether the corporation has contributed to the abuse. ${ }^{86}$ It follows that the responsibility to respect will be engaged when MNCs cause, contribute to, or have direct links through their supply chain with modern slavery. The latter two refer to complicity, a concept with both legal and non-legal meanings. ${ }^{87}$ Contributing to forced labour may engage legal and non-legal complicity, while connections to forced labour are more likely to give rise only to non-legal complicity. ${ }^{88}$ National law may provide for criminal or civil liability where corporations are complicit in the commission of forced labour, for example, through aiding and abetting. This relates to the third pillar, access to redress, and states approaches in this regard will be explored further in section $\mathrm{C}$.

As a non-legal matter, MNCs may be perceived by the public as complicit in forced labour that occurs within their supply chains simply through their connection to it and the benefits they derive from it, regardless of actual legal liability. ${ }^{89}$ Indeed, as a result of

\footnotetext{
${ }^{79}$ Knox (n 50) 29.

${ }^{80}$ ibid 30.

${ }^{81}$ Kasey L McCall-Smith, 'Tides of Change - the State, Business and the Human' in Richard Barnes and Vassillis Tzevelekos (eds), Beyond Responsibility to Protect: Generating Change in International Law (Intersentia 2016) 219, 226.

${ }^{82}$ UNHRC (n 5) para 73; UNHRC, Report of the Special Representative of the Secretary-General on the Issue of Human Rights and Transnational Corporations and other Business Enterprise (15 May 2008), UN Doc A/HRC/8/16 para 26.

${ }^{83}$ Amol Mehra and Katie Shay, 'Corporate Responsibility for Modern Forms of Slavery' (2016) 14 JICJ 453, 457.

${ }^{84}$ UNGPs (n 8) 14.

85 ibid.

${ }^{86}$ ibid.

${ }^{87}$ UNGPs (n 8) 18.

${ }^{88}$ UNHRC (n 82) para 41.

${ }^{89}$ ibid para 27.
} 
advances in technology and heightened awareness of the connection between business and human rights, MNCs are increasingly held accountable by the public where forced labour is detected in their supply chains. ${ }^{90}$ Causing or being complicit in forced labour can have negative consequences for corporations, including divestment, reputational damage and a fall in share prices. ${ }^{91}$ Thus, the responsibility to respect can be 'socially' enforced through the 'courts of public opinion'. ${ }^{92}$ Coupled with potential for litigation in national courts, forced labour presents a significant risk to MNCs, creating a viable 'business case' for corporations to prevent and redress it. ${ }^{93}$ Indeed, MNCs can derive a number of reputational benefits from combating forced labour, enabling them to attract socially conscious consumers and investors. $^{94}$

To avoid complicity, corporations should exercise due diligence 'to become aware of, prevent and address' human rights abuses with which they are directly or indirectly involved through their activities or business relationships. ${ }^{95}$ The concept of due diligence is central to this pillar. It is a term familiar to human rights law in relation to state duties regarding nonstate actors, and to business practices in relation to the management of financial risks. ${ }^{96}$ The precise scope of human rights due diligence varies according to context. ${ }^{97}$ At a minimum, it should include embedding a publicly-available policy throughout the business enterprise, including supply chains; ongoing assessment of 'actual and potential human rights impacts'; integrating and acting upon the findings; tracking human rights performance and compliance through monitoring and auditing; communicating results internally and externally; and a remediation process where human rights abuses have already occurred. ${ }^{98}$ Since due diligence requires corporations to take proactive steps to monitor and influence their global supply chains, it could be an important tool for identifying and tackling forced labour.

The responsibility to respect exists separately from and in addition to a corporation's obligation to comply with national laws and a state's ability or willingness to protect against

\footnotetext{
${ }^{90}$ See eg Annie Kelly, 'Hitachi and Canon not doing enough to tackle forced labour, says new report' The Guardian (23 June 2016) <www.theguardian.com/sustainable-business/2016/jun/23/hitachi-canon-ictcompanies-forced-labour-supply-chain-benchmark-report> accessed 13 July 2017.

${ }^{91}$ UNHRC (n 5) para 75; E. Christopher Johnson, 'The Corporate Law, Human Trafficking, and Child Labor: Who's in Your Supply Chain?’ (2013) 30(1) Thomas M Cooley Law Review 27, 28.

${ }^{92}$ UNHRC (n 5) para 54.

${ }^{93}$ Johnson (n 91) 33.

${ }^{94}$ ibid.

${ }^{95}$ UNHRC (n 5) para 73.

${ }^{96}$ ibid para 56.

${ }^{97}$ ibid para 25.

${ }^{98}$ UNGPs (n 8) 16, 19, 20-24.
} 
human rights violations. ${ }^{99}$ Thus, MNCs have a responsibility to adhere to international standards, regardless of whether those standards are effectively enforced in the different national contexts in which they operate. ${ }^{100}$ This means that poor human rights and worker protections in host states do not exculpate corporations. MNCs are often well-placed to tackle forced labour due to their resources, power and influence enabling them to control and pressurise suppliers. ${ }^{101}$ This is central to closing the 'governance gap' and increasing human rights protection. It also compensates for the limitations of some states and failure of others to adequately fulfil their duty to protect. ${ }^{102}$

As part of their responsibility to respect, corporations must strive for policy coherence. ${ }^{103}$ There is a tendency for corporations, like states, to isolate their human rights policies from the policies that govern their wider activities, sometimes leading to policy incoherence and contradictory behaviour. ${ }^{104}$ This is particularly relevant to forced labour. The demanding purchasing and production practices of corporations, which seek a fast turnaround, often increase the likelihood of exploitative working conditions. ${ }^{105}$ An OXFAM study on Unilever, for example, found that although Unilever had a human rights due diligence policy, its purchasing practices had an adverse impact on workers since they imposed challenging requirements on suppliers. ${ }^{106}$ Corporations are often reluctant to review how their purchasing practices may contribute to modern slavery. ${ }^{107}$ Yet, modern slavery is not simply an exogenous aberration which corporations have to manage, but a structural problem generated by the broader economic conditions constituted in part by corporations themselves. ${ }^{108}$ Structural problems require structural solutions ${ }^{109}$ that address the root of the problem as well

\footnotetext{
99 ibid 13.

${ }^{100}$ Oxfam (n 60) 6.

${ }^{101}$ Jonathan Todres, 'The Private Sector's Pivotal Role in Combating Human Trafficking' (2012) 3 California L Rev Circuit 3 (2012) 80, 86.

102 ibid.

${ }^{103}$ UNGPs (n 8) 17.

${ }^{104}$ UNHRC (n 5) para 62.

${ }^{105}$ New (n 57) 702; Doreen McBarnet and Marina Kurkchiyan, 'Corporate Social Responsibility through Contractual Control? Global Supply Chains and 'Other-Regulation' in Doreen McBarnet, Aurora Voiculescu and Tom Campbell (eds), The New Corporate Accountability: Corporate Social Responsibility and the Law (Cambridge University Press 2007) 59, 88; Gillian B White, 'All Your Clothes Are Made with Exploited Labor' The Atlantic (3 June 2015) <www.theatlantic.com/business/archive/2015/06/patagonia-labor-clothing-factoryexploitation/394658/> accessed 13 July 2017.

${ }^{106}$ Rachel Wilshaw and others, Labour Rights in Unilever's Supply Chain: From Compliance towards Good Practice. An Oxfam Study of Labour Issues in Unilever's Vietnam Operations and Supply Chain (Oxfam 2013) 8.

${ }^{8 .}$ McBarnet and Kurkchiyan (n 105) 88.

${ }^{108}$ New (n 57) 697.

${ }^{109}$ Mary Dowell-Jones, 'Financial Institutions and Human Rights' (2013) 13(3) H R L Rev 423, 427.
} 
as 'isolated problems factory by factory'. ${ }^{110}$ Thus, integrating and embedding human rights policies throughout corporate operations is essential to tackling forced labour.

\section{Access to remedies}

The final pillar recognises that victims of corporate-related human rights harm need access to remedies and grievance mechanisms. ${ }^{111}$ This is important to both the state duty to protect and the corporate responsibility to respect. ${ }^{112}$ Grievance mechanisms can be defined as the varied processes 'through which grievances concerning business-related human rights abuse can be raised and remedy can be sought'. ${ }^{113}$ They may take a range of substantive forms and be judicial or non-judicial; state-based or non-state based. ${ }^{114}$ They not only provide redress for victims, but also function as 'bottom up' tools that complement 'top down' mechanisms to increase corporate accountability. ${ }^{115}$ Procedurally, they should always be impartial, corruption-free and independent. ${ }^{116}$ In many countries access to effective judicial and nonjudicial redress for victims of business-related harm is limited. ${ }^{117}$ This is especially true for victims of forced labour, notwithstanding the many injustices they suffer.

When business-related human rights harm occurs within a state's territory or jurisdiction, states must ensure that victims are aware of and have access to effective remedies. ${ }^{118}$ This encompasses investigating, punishing, and redressing the harm. ${ }^{119}$ Like the state duty to protect, this aspect of the remedy pillar is grounded in the existing obligations to which states are subject under international human rights law: access to justice is a human right. ${ }^{120}$ States have discretion in choosing remedies, but should adopt appropriate judicial, administrative and legislative mechanisms. ${ }^{121}$ Human rights treaty bodies increasingly recommend that states establish criminal and civil corporate liability for human rights abuses that fall within their jurisdiction. ${ }^{122}$ Establishing liability is arguably the most appropriate form of state-based redress for corporations complicit in forced labour. On an international level, modern slavery is a criminal offence and should be recognised as such in domestic law

\footnotetext{
${ }^{110}$ White (n 105).

${ }^{111}$ UNGPs (n 8) 1.

${ }^{112}$ UNHRC (n 5) para 82.

${ }^{113}$ UNGPs (n 8) 27.

114 ibid.

${ }^{115}$ Oxfam (n 60) 5.

${ }^{116}$ UNGPs (n 8) 27.

${ }^{117}$ UNHRC (n 5) para 102.

${ }^{118}$ UNGPs (n 8) 27-28.

119 ibid 27.

${ }^{120}$ See ICCPR art 2(3); ECHR art 13; ACHR art 25.

${ }^{121}$ UNGPs (n 8) 27; HRC (n 45) para 15.

${ }^{122}$ UNHRC (n 5) para 83.
} 
to ensure adequate punishment and accountability. ${ }^{123}$ It can also amount to a range of civil wrongs and, accordingly, corporate defendants should be liable for damages resulting from the harm suffered by victims.

Judicial mechanisms must be accessible and effective. ${ }^{124}$ States must proactively consider ways to reduce legal and practical barriers to access to remedy, including for foreign plaintiffs against corporations based or operating in their territory. ${ }^{125}$ Foreign plaintiffs may seek to claim against MNCs in home states when they are unable to secure adequate redress from suppliers in host states where the harms occurred because of, inter alia, the insufficient resources of the supplier or weak domestic law. ${ }^{126}$ The UNGPs highlight three key legal barriers to such claims that are all relevant to forced labour. Firstly, victims may be prevented from seeking remedy from MNCs in home states because of jurisdictional issues and forum non conveniens. ${ }^{127}$ Secondly, company law doctrines, such as separate legal personality, coupled with the limited legal recognition of corporate groups as single economic entities, mean that top-tier MNCs and their suppliers are viewed as autonomous and separate. ${ }^{128}$ The 'corporate veil' means MNCs are not generally liable for wrongs committed within their supply chains, regardless of the realities of economic control. ${ }^{129}$ This allows corporations to structure their activities to avoid liability for claims arising out of forced labour within their supply chain. Finally, in some states certain groups, such as indigenous persons and migrants, are excluded from some types of legal protection, making them especially vulnerable to forced labour. ${ }^{130}$ Practical and procedural barriers include the costs of bringing cases and difficulty in securing legal representation. ${ }^{131}$

This pillar also encompasses non-state based grievance mechanisms, which are expected to meet certain criteria. ${ }^{132}$ Corporations should ensure that victims of human rights harm have access to remedies through establishing effective operational-level grievance

\footnotetext{
123 Trafficking Protocol art 5.

${ }^{124}$ UNGPs (n 8) 28-29.

125 ibid.

${ }^{126}$ Richard Meeran, 'Access to Remedy: The United Kingdom Experience of MNC Tort Litigation for Human Rights Violations' in Surya Deva and David Bilchitz (eds), Human Rights Obligations of Business: Beyond the Corporate Responsibility to Respect? (Cambridge University Press 2013) 378, 382.

${ }^{127}$ UNGPs (n 8) 29; Debra Cohen Maryanov, 'Sweatshop Liability: Corporate Codes of Conduct and the Governance of Labor Standards in the International Supply Chain' (2010) 14(1) Lewis Clark L Rev 397, 41216.

${ }^{128}$ Kurt A Strasser and Philip Blumberg, 'Legal Form and Economic Substance of Enterprise Groups: Implications for Legal Policy’ (2011) 1(1) Accounting, Economics and Law 1, 2-3.

${ }^{129}$ UNHRC (n 5) para 13.

${ }^{130}$ UNGPs (n 8) 29.

131 ibid.

132 ibid 33-34.
} 
mechanisms as part of their socially-grounded responsibility to respect. ${ }^{133}$ States have a duty to facilitate access to non-state based grievance mechanisms. ${ }^{134}$ These types of mechanisms could provide remedies for forced labour victims in circumstances when courts cannot provide effective remediation. ${ }^{135}$ Forced labour does not need to occur before it is brought to the attention of MNCs; MNCs could be alerted to concerns about severe working conditions. ${ }^{136}$ This could assist MNCs with their human rights due diligence processes and facilitate the early identification of modern slavery, thereby preventing it from escalating. ${ }^{137}$

\section{IMPLEMENTATION}

When it comes to implementation of the UNGPs 'one size does not fit all' and different approaches can be, and have been, adopted for different human rights abuses. ${ }^{138}$ This section will analyse the effectiveness of three key techniques used to address forced labour. Some of these predated the UNGPs but nevertheless serve as examples of how the UNGPs can be implemented.

\section{Transparency and reporting}

State efforts to regulate forced labour in corporate supply chains have predominantly taken the form of increasing transparency by mandating corporations to publicly disclose their modern slavery policies. The US California Transparency in Supply Chains Act $2010^{139}$ ('CTSCA') and the UK Modern Slavery Act 2015 ${ }^{140}$ ('MSA') require large corporations that meet a certain threshold to publish reports on their websites that disclose the steps they take, if any, to monitor and manage modern slavery within their supply chains. ${ }^{141}$ If a corporation has taken no steps, it must issue a statement to that effect. ${ }^{142}$ Rather than requiring specific information to be disclosed, both Acts instead provide a non-exhaustive list of examples, such as, risk assessments; supplier codes of conduct; audits; training and internal accountability procedures; and certification by suppliers. ${ }^{143}$ In effect, the CTSCA and MSA require corporations to disclose the extent to which they exercise human rights due diligence to address forced labour. This approach complements a more general trend of legislative

\footnotetext{
${ }^{133}$ UNHRC (n 5) para 93.

${ }^{134}$ UNGPs (n 8) 31.

135 ibid 30 .

${ }^{136}$ ibid 32

137 ibid.

${ }^{138}$ UNHRC (n 34) para 15.

${ }^{139}$ California Transparency in Supply Chains Act of 2010 (CTSCA), Senate Bill No. 657, State of California.

${ }^{140}$ UK Modern Slavery Act 2015 (MSA), c30.

${ }^{141}$ CTSCA (n 139) paras 3(a)(1), 3(D)(b); MSA (n 140) ss 54(2), 54(4)(a), 54(7).

${ }^{142}$ CTSCA (n 139) para 3(D)(c); MSA (n 140) s 54(4)(b).

${ }^{143}$ CTSCA (n 139) para 3(D); MSA (n 140) s 54(5).
} 
reporting which requires MNCs to report on the social and environmental impact of their global operations. ${ }^{144}$ Although this legislation does not exclusively address forced labour, the resultant reports can encompass it. ${ }^{145}$

The CTSCA and MSA are relatively broad in scope; they apply to any corporation which conducts business in California and the UK respectively, regardless of where it is incorporated. ${ }^{146}$ Furthermore, by mandating reporting requirements which extend to corporate supply chains regardless of where the suppliers are based, this type of legislation has extraterritorial reach and helps bridge the 'governance gap'. It enhances governmental oversight of global supply chains and to some extent overcomes the jurisdictional hurdles to tackling forced labour faced by states outlined in the previous chapter. In both the CTSCA and MSA, however, it is unclear how far down the supply chain the reporting requirements extend. ${ }^{147}$ The CTSCA emphasises the 'direct supply chain', suggesting the requirements apply primarily to corporations' direct suppliers. ${ }^{148}$ The MSA appears to be broader and encompass the whole supply chain, though this has been challenged by some commentators. ${ }^{149}$ This is problematic since forced labour tends to occur further down supply chains. $^{150}$

By increasing transparency and public scrutiny of MNCs' forced labour policies, the MSA and CTSCA indirectly encourage corporations to exercise due diligence. This indirect approach is endorsed by the UNGPs. ${ }^{151}$ It amounts to implementation of the state duty to protect, by strengthening the corporate responsibility to respect at the domestic level. The resulting reports make it easier for NGOs, the media and the public to 'shame' corporations and hold them to account. ${ }^{152}$ Increased transparency also allows consumers and investors to make more informed decisions, preventing them from inadvertently supporting forced labour. ${ }^{153}$ Theoretically, this should incentivise corporations to exercise due diligence to address forced labour; otherwise, they may lose consumer approval, market share and

\footnotetext{
${ }^{144}$ See eg US Dodd-Frank Wall Street Reform and Consumer Protection Act 2010, Pub L No 111-203, H. R. 4173)s1502; UK Companies Act 2006, c 46, at s 414A, 414C.

${ }^{145}$ Mehra and Shay (n 83) 463.

${ }^{146}$ MSA (n 140) s 54(12); CTSCA (n 139) § 3(a)(1).

${ }^{147}$ New (n 57) 700.

${ }^{148}$ CTSCA (n 139) § 3(a)(1).

${ }^{149}$ Parosha Chandran, 'A Loophole in the Slavery Bill Could Allow Companies to Hide Supply Chain Abuses' The Guardian (24 March 2015) <www.theguardian.com/global-development/2015/mar/24/loophole-modernslavery-bill-transparency-supply-chain-abuses> accessed 13 July 2017.

${ }^{150}$ Eckert (n 4) 414.

${ }^{151}$ UNGPs (n 8) 4.

152 Greer and Purvis (n 10) 60.

153 ibid 57.
} 
competiveness. ${ }^{154}$ Thus, this legislation leverages market and societal pressures rather than legal liability. ${ }^{155}$ It could also reduce consumer-based demand for cheap goods and services a major part of the problem - where these are tainted by slavery. ${ }^{156} \mathrm{MNC}$ involvement in forced labour is sometimes a result of their "willful blindness' ${ }^{157}$ and the complexity and opaqueness of contemporary supply chains rendering forced labour hidden. ${ }^{158}$ Encouraging corporations to educate themselves about their supply chains and to increase transparency is vital to uncovering forced labour. ${ }^{159}$

For the MSA and CTSCA to be effective, social actors need to engage with the information made available. ${ }^{160}$ There are numerous examples of high-profile instances where exposure of modern slavery in global supply chains has been traced back to MNCs, such as Nike and Nestlé. ${ }^{161}$ Many respond by voluntarily enhancing their human rights due diligence policies and publishing extensive supply chain disclosures to restore their reputations. ${ }^{162}$ Societal pressure can also trigger collective change. For example, in response to pressure from workers in Florida, MNCs including Subway and Burger King committed to the Fair Food Program which aims to eliminate forced labour in the tomato industry. ${ }^{163}$ Public pressure also led to fish from a Thai supplier associated with forced labour being removed from supermarkets across Europe and the US. ${ }^{164}$ Market and societal forces, therefore, can be powerful.

On the other hand, the impact of these forces varies between industry sectors. Social pressure is stronger and brand recognition is more valuable to MNCs in industries that specialise in consumer rather than industrial goods. ${ }^{165}$ Additionally, while the MSA applies to corporations that provide goods and services, the CTSCA is limited to corporations that

\footnotetext{
154 ibid 60.

${ }^{155}$ New (n 57) 700.

${ }^{156}$ Johnson (n 91) 30.

${ }^{157}$ Greer and Purvis (n 10) 64.

${ }^{158}$ Naomi Jiyoung Bang, 'Casting a Wide Net to Catch the Big Fish: A Comprehensive Initiative to Reduce Human Trafficking in the Global Seafood Chain' (2014) 17(3) U of Pa J L Soc Change 221, 227.

${ }^{159}$ Gold, Trautrims and Trodd (n 29) 488.

${ }^{160}$ New (n 57) 703.

${ }^{161}$ See eg Joe Clarke, 'Child labour on Nestlé farms: chocolate giant's problems continue' The Guardian (2 September 2015) <www.theguardian.com/global-development-professionals-network/2015/sep/02/child-labouron-nestle-farms-chocolate-giants-problems-continue> accessed 13 July 2017; Marc Gunther, 'Under pressure: campaigns that persuaded companies to change the world' The Guardian (9 February 2015) $<$ www.theguardian.com/sustainable-business/2015/feb/09/corporate-ngo-campaign-environment-climatechange $>$ accessed 13 July 2017.

${ }^{162}$ Doorey (n 2) 598.

${ }^{163}$ Mehra and Shay (n 83) 460.

${ }^{164}$ Gold, Trautrims and Trodd (n 29) 486.

${ }^{165}$ McBarnet and Kurkchiyan (n 105) 83.
} 
produce tangible goods. ${ }^{166}$ This is problematic since, although the risk of modern slavery is greater in certain industries, it is not confined to them, occurring across the global economy. Moreover, although the number of ethical shareholders, investors and consumers are growing, they remain a minority. ${ }^{167}$ In short, there is no guarantee that disclosure will have any consequences at all. ${ }^{168}$

Research suggests that companies have responded positively to the CTSCA and imposed new requirements on their suppliers. ${ }^{169}$ Other research indicates, however, that corporate responses are varied, with some producing detailed reports while others simply reproduce the language of the statute or state that they are not taking any measures. ${ }^{170}$ Similarly, a study of the first one hundred MSA statements found them to lack meaningful detail. ${ }^{171}$ Some scholars argue that these inconsistencies are a result of the vague formulation of the disclosure requirements in both statutes ${ }^{172}$ which enable corporations to make 'empty, airy statements that mean nothing. ${ }^{173}$ In any case, some argue, in absence of a requirement for independent third-party verification, reports may simply amount to corporate 'greenwashing'. ${ }^{174}$ Worse still, corporations that expose themselves to public scrutiny by providing detailed reports in good faith may be disadvantaged in comparison to their competitors and consequently this might discourage transparency. ${ }^{175}$ This suggests that to make the reports more uniform, reliable and transparent, the disclosure requirements need to be made more specific and third-party verification made mandatory.

An alternative approach advocated by some scholars is to make full supply chain disclosure mandatory for MNCs. ${ }^{176}$ This would result in greater transparency which would further empower NGOs and the media to hold MNCs accountable and thus encourage corporations to better monitor working practices within their supply chain. ${ }^{177}$ Some MNCs argue, however, that it is impractical because supply chains are constantly changing and it amounts to confidential commercial information. ${ }^{178}$ Doorey dismisses the latter argument on

\footnotetext{
${ }^{166}$ CTSCA (n 139) § 3(c); MSA (n 140) s 54(2)(a).

${ }^{167}$ Connolly (n 63) 1234-5.

${ }^{168}$ Bang (n 158) 243.

${ }^{169}$ Shavers (n 30) 80-81.

${ }^{170}$ Todres (n 101) 95.

${ }^{171}$ Ergon Associates, Reporting on Modern Slavery: The Current State of Disclosure - May 2016 (Ergon Associates, 2016) 3.

172 Eckert (n 4) 400.

${ }^{173}$ New (n 57) 701.

${ }^{174}$ Eckert (n 4) 401.

175 ibid 400.

${ }^{176}$ New (n 57) 703.

${ }^{177}$ Doorey (n 2) 588.

178 ibid.
} 
the basis that some MNCs, like Nike and Levi, have already disclosed their factory lists. ${ }^{179}$ MNCs could also establish long-term business relationships with suppliers to make the disclosure requirements more manageable. ${ }^{180}$ It could provide opportunities for collaboration between MNCs that use the same suppliers, strengthening their compliance mechanisms and increasing efficiency by reducing duplication of monitoring. ${ }^{181}$ Ultimately, however, this approach suffers from the same shortcomings of other transparency measures that rely on public opinion. Overall, tackling modern slavery requires more than reporting and transparency requirements. While this legislation can lead to some improvements by increasing societal and market pressures, its impact is always likely to be indirect and somewhat limited.

Neither the CTSCA nor the MSA require corporations to exercise due diligence. Under the Acts, corporations must simply report what, if anything, they have voluntarily done to address forced labour. ${ }^{182}$ Corporations are not penalised for failing to exercise due diligence. New argues that this legislation lacks 'teeth' and by deploying corporations to regulate themselves and their suppliers, it provides only a limited role for the home and host state in monitoring corporate activity. ${ }^{183}$ On this interpretation, reporting and transparency legislation is insufficient to fulfil the state duty to protect, fails to address the remedy pillar and may be another manifestation of state reluctance to directly regulate corporate activity. Some scholars argue that to meet the duty to protect, states must monitor corporate activity and harden the corporate responsibility to respect at the domestic level by obliging MNCs to carry out human rights due diligence, rather than rely on corporate self-regulation. ${ }^{184}$ On the other hand, Eckert argues that in light of the size and number of MNCs and the limited resources of states, reliance upon corporate self-regulation makes the governance of corporate supply chains 'practically feasible'. ${ }^{185}$ Imposing legally binding requirements on MNCs in relation to their entire supply chain may be unrealistic given their fluid and rapidly changing nature. $^{186}$

\section{Corporate codes of conduct and due diligence policies}




In recent decades, growing numbers of MNCs have adopted codes of conduct that extend to their suppliers in response to increased concerns about the social environmental impacts of their supply chain and to the rising prominence of Corporate Social Responsibility ${ }^{187}$ ('CSR'). CSR refers to 'the integration of social, environmental, and economic concerns into business operations'. ${ }^{188}$ It is distinctive from, though related to, the business and human rights agenda. Although these codes are voluntary in nature, they create behavioural expectations. ${ }^{189}$ Since the UNGPs were published the number of codes has increased and many now refer to the UNGPs. ${ }^{190}$ By enabling corporations 'to identify, prevent, mitigate and plan to redress human rights abuses', these codes can amount to the exercise of due diligence in fulfilment of the corporate responsibility to respect. ${ }^{191}$ The content of these codes varies and they tend to address a range of issues, but the majority pinpoint labour issues as a primary concern. ${ }^{192}$

Codes of conduct have long been adopted by corporations and many are accompanied by well-established procedures to monitor and enforce supplier compliance. ${ }^{193}$ Individual MNCs adopt varied procedures but Mitkidis summarises the general approach as having three elements: preventive monitoring, relational enforcement and contract termination. ${ }^{194}$ Preventive monitoring entails detecting non-compliance and is usually carried out through auditing. Faced with non-compliance, corporations can choose either to engage or disengage with the supplier. ${ }^{195}$ Disengagement (contract termination) is not generally favoured as it does not aim to change supplier behaviour and improve working conditions. ${ }^{196}$ Best practice is considered to be engagement through relational enforcement. On this approach, top-tier MNCs engage in long-term relationships with suppliers to address non-compliance, helping them to improve as part a 'continuous development process' ${ }^{197}$ Contractual termination is used only as a last resort. ${ }^{198}$

\footnotetext{
${ }^{187}$ Nolan (n 3) 148.

${ }^{188}$ Shavers (n 30) 65.

${ }^{189}$ Vytopil (n 66) 156.

${ }^{190}$ Business \& Human Rights Resource Centre, 'Corporate Responsibility to Respect: 5 years on' (Business \& Human Rights Resource Centre)

$<$ www.business-humanrights.org/sites/default/files/images/Respect\%20Final.png> accessed 13 July 2017.

${ }^{191}$ Mehra and Shay (n 83) 458.

${ }^{192}$ American Bar Association and Arizona State University, Do Fortune 100 Corporations Address Potential Links to Human Rights Violations in a Globally Integrated Economy? ABA/ASU Study on Publicly Available Policies on Forced Labour, Human Trafficking, and the Trade in Conflict Minerals (Arizona State University, 2014) 1.

${ }^{193}$ Andersen and Skjoett-Larsen (n 7) 78.

${ }^{194}$ Mitkidis (n 62) 20-22.

${ }^{195}$ See also Diana Winstanley, Joanna Clark and Helena Leeson, 'Approaches to Child Labour in the Supply Chain' (2002) 11(3) Business Ethics: A Eur Rev 210, 222.

${ }^{196}$ Mitkidis (n 62) 22.

197 Andersen and Skjoett-Larsen (n 7) 78.

${ }^{198}$ Mitkidis (n 62) 22.
} 
This leads to the question of whether traditional procedures adopted to enforce codes of conduct can be effective in tackling forced labour. There is some evidence that codes have raised business awareness of forced labour and improved working conditions in global supply chains. ${ }^{199}$ Since the codes are widely adopted, they may gradually standardise corporate respect of human rights and the elimination of forced labour in supply chains, triggering a 'race to the top'. ${ }^{200}$ They also provide a standard from which an individual corporation's human rights performance can be judged, enabling social actors to 'name and shame' corporations who fail to meet their own stated commitments. ${ }^{201}$ Despite these potential benefits, businesses continue to cause or contribute to forced labour. ${ }^{202}$ Gaps between the standards expressed in codes and the working conditions within supply chains are common. ${ }^{203}$ This suggests that the current mechanisms used for enforcing codes are not effective in tackling forced labour.

A number of issues arise with the application of traditional due diligence policies to forced labour. Auditing tends to detect only immediately visible issues. ${ }^{204}$ Moreover, because forced labour is a criminal activity, it is often actively hidden by perpetrators, making it difficult to detect compared to other CSR issues. ${ }^{205}$ Auditors may struggle to get full access to facilities and victims are often unwilling to discuss their circumstances with them. ${ }^{206}$ The complexity of global supply chains further conceals victims, particularly since forced labour tends to occur in the lower-tiers of supply chains which are inherently the most challenging to monitor. ${ }^{207}$ Hence, the majority of MNCs only monitor direct, first-tier suppliers. ${ }^{208}$ In short, conventional auditing and monitoring processes may be inadequate for detecting forced labour. Hence, forced labour has been discovered in the supply chains of MNCs with welldeveloped CSR regimes. ${ }^{209}$ Additionally, when it is detected, its illegality arguably also removes engagement as an option, since knowing engagement could expose MNCs to criminal liability. ${ }^{210}$ Conversely, contract termination and the withdrawal of sourcing from

\footnotetext{
${ }^{199}$ Kirsten Newitt, 'Private Sector Voluntary Initiatives on Labor Standards' Background Paper for the World Development Report 2013 (Ergon Associates, 2013) 4, 30.

${ }^{200}$ Shavers (n 30) 68.

${ }^{201}$ Ratner (n 64) 533.

${ }^{202}$ Mehra and Shay (n 83) 458.

${ }^{203}$ Andersen and Skjoett-Larsen (n 7) 78.

${ }^{204}$ McBarnet and Kurkchiyan (n 105) 77.

${ }^{205}$ Gold, Trautrims and Trodd (n 29) 488.

${ }^{206}$ Eckert (n 4) 402.

207 ibid 403.

${ }^{208}$ Andersen and Skjoett-Larsen (n 7) 83.

${ }^{209}$ New (n 57) 702.

210 ibid 699.
} 
host states following the detection of forced labour might actually have negative socioeconomic implications and exacerbate the risk of forced labour within countries. ${ }^{211}$

For human rights due diligence to be effective in tackling forced labour, it must go beyond basic auditing and extend to the lower-tiers of supply chains. This is challenging given the difficulties in controlling extensive supply chains comprised of firms in different social, political and geographical settings, ${ }^{212}$ some of whom MNCs may have no direct legal relationship. $^{213}$ There are, however, ways of trying to overcome these challenges. For example, 'supply chain mapping' - the process through which high-risk areas of the supply chain are identified and prioritised for human rights due diligence - is endorsed in the UNGPs. ${ }^{214}$ Operational-based grievance mechanisms might also counteract the shortcomings of auditing by providing a 'bottom up' route through which modern slavery can be detected. Corporations could also collaborate where they use the same facilities. ${ }^{215}$ Ultimately, however, this will require significant resources. ${ }^{216}$ This may be more feasible for larger MNCs than small-to-medium size corporations. ${ }^{217}$ Indeed, some argue that since corporations cannot feasibly control their entire supply chain, it is too much to expect all corporations to exercise due diligence in relation to it. ${ }^{218}$ Ruggie highlights, however, that the scope of due diligence is not unlimited and takes into account differences between MNCs. ${ }^{219}$ Corporations are not expected to exercise due diligence in relation to every entity over which they have some influence, but strategically to avoid being a 'causal agent' or complicit in human rights harms. $^{220}$

The resources and efforts necessary for MNCs to conduct effective due diligence to address forced labour nevertheless remains problematic. The perpetration of forced labour is motivated by profit. $^{221}$ In most jurisdictions, the primary function of corporations is to maximise shareholder value and directors have fiduciary duties to this end. ${ }^{222}$ Forced labour poses reputational and litigious risks to MNCs which can have an adverse impact on their

\footnotetext{
${ }^{211}$ White (n 105).

${ }^{212}$ Esben Rahbek Pedersen and Mette Andersen, 'Safeguarding Corporate Social Responsibility (CSR) in Global Supply Chains: How Codes of Conduct are Managed in Buyer-Supplier Relationships' (2006) 6(3-4) J Public Affairs 228, 237.

${ }^{213}$ Mitkidis (n 75) 19.

${ }^{214}$ UNGPs (n 8) 18; Oxfam (n 60) 4.

${ }^{215}$ Eckert (n 4) 404.

${ }^{216}$ White (n 105).

217 Gold, Trautrims and Trodd (n 29) 489.

${ }^{218}$ Eckert (n 4) 403.

${ }^{219}$ UNGPs (n 8) 18, 15.

${ }^{220}$ UNHRC (n 5) para 72.

${ }^{221}$ Greer and Purvis (n 10) 56

${ }^{222}$ Connolly (n 63) 1233.
} 
share value. Thus, it is possible to construct a 'business case' for eliminating forced labour from supply chains aligned with the profit maximization goal. Statistics suggest, however, that in practice only a minority of MNCs view forced labour as a credible threat. ${ }^{223}$ Furthermore, although direct perpetrators of forced labour retain the bulk the profits derived from the crime, ${ }^{224}$ it can still increase corporate profits through lower labour costs. ${ }^{225}$ Sourcing labour from suppliers in host states with adequate human rights standards and conducting effective due diligence may increase production costs. ${ }^{226}$ Thus, the elimination of forced labour may conflict with the goal of profit maximization. Directors have a legal obligation to maximise profits but not a legal obligation to combat forced labour. In many ways, therefore, the prevailing legal framework governing MNCs can be counterproductive to the elimination of forced labour.

This illuminates a fundamental difference between the CSR and human rights. CSR is ultimately 'bottom-line focused': it is designed to encompass social and environmental considerations in order to assist a corporation's business while having a broader positive impact on society. ${ }^{227}$ In CSR terms, forced labour is one amongst a number of social risks to be taken into account by corporations when assessing what is in the best financial interests of shareholders. Human rights, on the other hand, are 'person centred' and designed to vest individuals with universal rights and entitlements. ${ }^{228}$ In human rights terms, individuals have a right to be free from slavery and forced labour must always be prohibited. CSR codes are usually viewed as encompassing human rights, ${ }^{229}$ but this conflation of CSR and human rights is problematic and may impede the effectiveness of human rights due diligence. The UNGPs appear to partially acknowledge this distinction; they highlight that human rights impact assessments can be incorporated in existing CSR procedures but should explicitly refer to human rights. ${ }^{230}$ They also state that corporations should assess risks to rights-holders as well as risks to the company. ${ }^{231}$ Bang argues that to combat forced labour, corporations need to implement due diligence not only for their own benefit, but also for the benefit of victims. ${ }^{232}$ Corporate practice is yet to shift in this direction. It is questionable whether such a

\footnotetext{
${ }^{223}$ George and Smith (n 74) 110.

${ }^{224}$ Gold, Trautrims and Trodd (n 29) 486.

${ }^{225}$ Greer and Purvis (n 10) 57.

${ }^{226}$ Bang (n 158) 226-227.

${ }^{227}$ Connolly (n 63) 1236.

${ }^{228}$ McCorquodale (n 40) 391.

${ }^{229}$ ibid.

${ }^{230}$ UNGPs (n 8) 20.

${ }^{231}$ ibid 18.

${ }^{232}$ Bang (n 158) 247.
} 
shift, or even a better balance, can be achieved under a legal framework which prioritises shareholder interests and profit maximisation.

One solution may be to modify the fiduciary duties of directors to encompass a duty to exercise due diligence to address forced labour. Indeed, some states have passed legislation reframing the fiduciary duties of directors to encompass broader social and environmental considerations. Section 172 of the UK's Companies Act 2006, for example, adopts an 'enlightened shareholder value' approach which retains the profit maximisation goal, but instructs directors to consider non-financial, social and environmental considerations. ${ }^{233}$ The effectiveness of this 'enlightened' approach is, however, contested. ${ }^{234}$ Muchlinski argues that human rights due diligence requires going beyond an 'enlightened shareholder value' approach to encompass social and financial concerns on a more equal standing. ${ }^{235}$ In the context of forced labour, although section 172 suggests that it is something directors have a duty to consider, the interests of shareholders remain paramount. Some, like Connolly, argue that diluting the profit maximization goal with other compulsory non-financial considerations may actually be counterproductive, since it would leave greater scope for 'individuals to subvert the system for their own ends'. ${ }^{236}$ A better approach, he suggests, would be to retain shareholder primacy but to 'rig the system' through regulation that makes human rights violations unprofitable. $^{237}$

As it stands, human rights due diligence is voluntary. In keeping with the profit maximisation paradigm, the corporations that seem to have been most proactive in tackling forced labour are those who view it as a threat to their profitability. ${ }^{238}$ They seem to have acted primarily in response to market and social pressures and the potential financial losses inaction can bring, rather than as a matter of principle. ${ }^{239}$ This underlines both the potential value of transparency and reporting measures in increasing the reputational and profitability risks to corporations and their limitations: as indicated in the previous section, the impact of the 'court of public opinion' is uneven and inconsistent. Mehra and Shay argue that increasing the prospect of legal liability and thus financial penalties could incentivise MNCs

\footnotetext{
${ }^{233}$ UK Companies Act 2006, s 172(1)(d).

${ }^{234}$ See eg Stephen F Copp, 'S.172 of the Companies Act 2006 Fails People and Planet?' (2010) 31(12) Company Lawyer 406.

${ }^{235}$ Peter Muchlinski, 'Implementing the New UN Corporate Human Rights Framework: Implications for Corporate Law, Governance, and Regulation’ (2012) 22(1) Business Ethics Q 145, 167.

${ }^{236}$ Connolly (n 63) 1240.

237 ibid $1240-41$.

${ }^{238}$ Bang (n 158) 241.

${ }^{239}$ Mehra and Shay (n 83) 459.
} 
to combat forced labour, regardless of their sector or size. ${ }^{240}$ This could also reinforce the corporate responsibility to respect at the domestic level.

\section{Criminal and civil liability}

A growing minority of states are establishing corporate liability for breaches of national laws which reflect international standards. ${ }^{241}$ This links to all three pillars: states fulfil their duty to protect by increasing access to remedies for victims of corporate-related abuses and strengthening the corporate responsibility to respect by creating accountability. If states fail to establish corporate liability for forced labour, they may be in breach of their obligations under international law. ${ }^{242}$

\section{a) Criminal liability}

Historic slavery has long been criminalised and since the Trafficking Protocol more than 90\% of countries have criminalised modern slavery. ${ }^{243}$ International criminal tribunals only assume jurisdiction over natural persons, thereby excluding corporations. ${ }^{244}$ However, under international law, states are obliged to punish perpetrators of forced labour, including corporations. ${ }^{245}$ Thus, states are increasingly extending domestic criminal law to encompass corporate activity. ${ }^{246}$ Corporations may be criminally liable for forced labour perpetrators or through complicity. ${ }^{247}$ Theories imputing liability to corporations for complicity vary, but domestic criminal law is often influenced by international criminal law. ${ }^{248}$ Applying these rules to forced labour, MNCs may be considered to have aided and abetted where they knowingly provide assistance or encouragement, through act or omission, which has a substantial effect on the commission of forced labour by suppliers. ${ }^{249}$

In the US, the Trafficking Victims Protection Act 2000 ('TVPA') makes human trafficking and related offences a federal crime. ${ }^{250}$ The Act has since been expanded, making it a criminal act to knowingly benefit from modern slavery. ${ }^{251}$ This goes further than

\footnotetext{
240 ibid 458, 468.

${ }^{241}$ UNHRC (n 5) para 20.

${ }^{242}$ Eg Trafficking Protocol art 5; Rantsev (n 47) [283]-[289]; Siliadin (n 47) [112]; Case of CN v the United Kingdom App no 4239/08 (ECtHR, 13 November 2012) [66].

${ }^{243}$ UNODC 12.

${ }^{244}$ See eg, Rome Statute of the International Criminal Court (adopted on 17 July 1998, entered into force 1 July 2002, last amended 2010) 2187 UNTS 38544, art 25(1).

${ }^{245}$ Trafficking Protocol art 5; Siliadin (n 47) [89], [112]; Rantsev (n 47) [283]-[289].

${ }^{246}$ UNGPs (n 8) 19.

${ }^{247}$ Mehra and Shay (n 83) 457.

${ }^{248}$ UNHRC (n 82) para 33.

249 ibid para 35; Prosecutor $v$ Tadic (1997) ICTY, IT-94-1-T [692].

${ }^{250}$ US Victims of Trafficking and Violence Protection Act of 2000, Pub L No 106-386.

${ }^{251}$ US Trafficking Victims Protection Reauthorization Act of 2008 (H.R. 7311), 18 U.S.C. § 1589(b); See also US Trafficking Victims Protection Reauthorization Act of 2003 (TVPRA) (H.R. 2620); US Trafficking Victims Protection Reauthorization Act of 2005 (H.R. 972).
} 
international criminal law, under which merely benefiting from the abuse is unlikely to be sufficient to establish complicity. ${ }^{252}$ Some states in the US have also extended corporate liability in state law to forced labour within their supply chains. ${ }^{253}$ The UK MSA establishes new offences of modern slavery, including forced labour, and imposes harsh penalties on 'persons' that commit them. ${ }^{254}$ It is unclear from the wording of the Act whether this extends to corporations, but the House of Lords has suggested that it includes legal persons. ${ }^{255}$

Criminal liability addresses corporate human rights impunity and creates accountability. Despite some positive legislative developments, however, globally the number of convictions for forced labour is low. ${ }^{256}$ The majority of prosecutions are against individuals, not corporations. ${ }^{257}$ This is in part because it is difficult to attribute knowledge or intent to corporations and thus establish the mens rea required for criminal conviction. ${ }^{258}$ As a result, corporate executives tend to be more vulnerable to criminal liability than the corporation itself. The example of the UK Bribery Act suggests that holding corporate executives criminally liable for forced labour might make them take compliance within their global supply chains more seriously. ${ }^{259}$ Establishing a similar form of extraterritorial liability to bribery was considered, but dismissed, in the preparatory stages of the MSA. ${ }^{260}$

\section{b) Civil liability}

The most common approach to seeking judicial redress from corporations remains civil litigation. ${ }^{261}$ Forced labour can give rise to a range of civil wrongs, such as negligence, assault, battery, trespass to the person and false imprisonment. ${ }^{262}$ The two most important types of claims in this context have been statutory causes for action and conventional common law torts.

Victims of forced labour may seek to recover damages from a MNC in its home state when they cannot secure remedies from the supplier in the host state where the harm occurred. There are two key sets of obstacles to the success of these types of claim: the first are jurisdictional; the second derive from the 'corporate veil' which shields MNCs from liability

\footnotetext{
${ }^{252}$ UNHRC (n 82) para 41.

${ }^{253}$ Greer and Purvis (n 10) 64.

${ }^{254}$ MSA (n 140) s 1(1).

${ }^{255}$ HL Deb 23 February 2015, vol 759, col 1415.

${ }^{256}$ UNODC 1.

${ }^{257}$ Mehra and Shay (n 83) 466.

${ }^{258}$ McCorquodale (n 40) 394.

${ }^{259}$ UK Bribery Act 2010, c 23, ss 7-9.

${ }^{260}$ Rühmkorf (n 61) 231.

${ }^{261}$ See recent UK civil case Galdikas \& Ors v DJ Houghton Catching Services Ltd \& Ors [2016] EWHC 1376 (QB).

${ }^{262}$ Rühmkorf (n 61) 167.
} 
for the activities of its suppliers and subsidiaries. ${ }^{263}$ In the UK, forum non conveniens is no longer an obstacle for cases concerning the extraterritorial activities of UK corporations and other EU-domiciled defendants as a result of the Brussels Regulation, ${ }^{264}$ although the UK's decision to leave the EU has created uncertainty. The courts rarely pierce the 'corporate veil' in relation to parent-subsidiary corporations and usually only on the basis of fraud. ${ }^{265}$ They have, however, shown a willingness to achieve the same effects of veil-piercing by establishing direct liability of a parent company for harm suffered by its subsidiary's employees. ${ }^{266}$ In the English Court of Appeal case Chandler v Cape Plc, the superior knowledge and significant control exercised by a parent company over the health and safety policies of its subsidiary meant it had assumed responsibility to protect the employees and owed them a direct 'duty of care'. ${ }^{267}$ In determining whether a duty of care arose, the court stressed the level of control and knowledge the parent company had over its subsidiary's health and safety policies and working conditions. ${ }^{268}$

This kind of liability has yet to be established in the context of a buyer-supplier relationship. ${ }^{269}$ Some scholars argue that parent-subsidiary and buyer-supplier relationships are analogous and that this form of liability could thus be extended to the latter, particularly where the buyer exercises a 'high degree of control and involvement ... in its suppliers' ${ }^{270}$ It could be argued that when MNCs require suppliers to commit to codes of conduct which prohibit forced labour and monitor compliance, MNCs are assuming responsibility to protect the supplier's employees. ${ }^{271}$ This argument has yet to be made in the UK courts, but in the US a similar argument against Walmart by its supplier's employees who were subject to, inter alia, forced labour by that supplier was rejected by the court. ${ }^{272}$ Although Walmart had a code of conduct which publicly promised that it would monitor supplier compliance with labour standards, the court held this reflected a right to inspect, not a duty to inspect. ${ }^{273}$ In Canada, British Colombia's Supreme Court is to rule on a claim against Nevsun by Nevsun's

\footnotetext{
${ }^{263}$ Meeran (n 126) 382.

264 ibid 380; Council Regulation (EC) 44/2001 on jurisdiction and the recognition and enforcement of judgments in civil and commercial matters (Brussels Regulation) [22 December 2000], art 2(1), 6(1); Owusu v Jackson [2005] ECJ C 281/02 [46]; See also Simon Baughen, Human Rights and Corporate Governance Wrongs: Closing the Governance Gaps (Edward Elgar Publishing 2015) 43.

${ }^{265}$ See Adams $v$ Cape Industries plc [1990] Ch 433.

${ }^{266}$ Meeran (n 126) 387.

${ }^{267}$ Chandler v Cape Plc [2012] EWCA Civ 525 [80].

268 ibid.

${ }^{269}$ Maryanov (n 27) 430.

${ }^{270}$ Madeline Conway, 'A New Duty of Care? Tort Liability from Voluntary Human Rights Due Diligence in Global Supply Chains’ (2015) 40(2) Queen’s L J 40(2) (2015) 741, 772.

271 ibid 743-744.

${ }^{272}$ Doe I v Wal-Mart Stores, Inc 572 F (3d) 677 (9th Cir. 2009).

273 ibid, 8616-8617, 8619, 8623.
} 
supplier's employees that were subjected to forced labour on the basis that, inter alia, Nevsun owed them a direct duty of care due to its relevant control and knowledge over the contractor's policies. ${ }^{274}$ While this is promising, overall it is difficult to establish that parent companies owe a duty of care to their subsidiary's employees, let alone to those of their suppliers. Moreover, a duty of care is unlikely to arise where MNCs are not involved with their suppliers.

In the US, statutory civil actions are the most effective route to secure redress from corporations. The Trafficking Victims Protection Reauthorization Act 2003 makes provision for civil causes of action enabling victims to sue corporations engaging in forced labour for damages. ${ }^{275}$ In a recent case under the TVPA, for example, a company was ordered to pay $\$ 12$ million in damages to victims of human trafficking. ${ }^{276}$ The bulk of jurisprudence addressing corporate-related human rights harm has arisen under the Alien Tort Statute 1789 ('ATS'). ${ }^{277}$ The ATS allows aliens to sue for a tort that violated international law in US courts. ${ }^{278}$ These cases almost always concern violations of customary international law. ${ }^{279}$ The ATS reaches the conduct of private parties in three situations: where they violated a norm of international law that is recognised as extending to private parties without requiring state action, including the prohibition against slave trading; where they were acting under the 'color of law' or state authority; and where they aided and abetted an international law violation. ${ }^{280}$ The majority of ATS cases with corporate defendants have involved alleged complicity. ${ }^{281}$

Only a narrow set of sufficiently definite norms fall within the scope of the ATS. ${ }^{282}$ It is well-established that the prohibition of slavery is a norm of customary international law and a number of ATS cases have concerned corporate-related forced labour. ${ }^{283}$ For example, Cuban plaintiffs were awarded $\$ 80$ million in damages in a claim against a corporate

\footnotetext{
${ }^{274}$ Araya, Fshazion and Tekle v Nevsun Resources Ltd [20 November 2014] Supreme Court of British Colombia (Statement of Claim) <www.news1130.com/wp-content/blogs.dir/sites/9/2016/01/21/statement-of-claim.pdf> accessed 13 July 2017 [54], [91].

275 TVPRA 2003 (n 251) 18 U.S.C. $§ 1595$.

${ }^{276}$ Reuters, 'Indian workers awarded millions after US firm found guilty of trafficking' The Guardian (19 February 2015) <www.theguardian.com/world/2015/feb/19/indian-workers-awarded-millions-after-us-firmfound-guilty-of-trafficking $>$ accessed 13 July 2017.

${ }^{277}$ US Alien Tort Statute 1789, 28 USC $§ 1350$

278 ibid.

${ }^{279}$ Curtis A Bradley, 'State Action and Corporate Human Rights Liability' (2010) 85(5) Notre Dame L Rev $1823,1824$.

${ }^{280}$ ibid $1826-1827$.

${ }^{281}$ UNHRC (n 82) para 29; eg Doe v Unocal, 395 F.3d 932 (9th Cir. 2002).

${ }^{282}$ Sosa v Alvarez-Machain 542 U.S. 692 (2004).

${ }^{283}$ Doe v Unocal (n 281); Doe v Nestle, SA 748 F.Supp.2d 1057 (C.D. Cal. 2010).
} 
defendant for conspiring with the Cuban government in a forced labour scheme. ${ }^{284}$ Despite some successes, however, the question of corporate liability under the ATS is controversial. Some argue that international civil jurisdiction cannot extend to corporations on the basis that they are excluded from international criminal jurisdiction and are not subjects of customary international law. ${ }^{285}$ There is a circuit split on this issue. ${ }^{286}$ Some cases concerning forced labour have indicated corporate liability is possible, ${ }^{287}$ while others state corporations are immune from liability. ${ }^{288}$ The Supreme Court is yet to rule on this issue, despite it being referred to them in Kiobel. ${ }^{289}$ Until the Supreme Court does so, it seems it is for states to determine whether corporations can incur civil liability based on customary international law within the domestic legal order. ${ }^{290}$

The ATS effectively creates a form of extraterritorial civil jurisdiction, though its scope has been severely curtailed by Kiobel, where the Supreme Court held that claims had to 'touch and concern the territory of the US ... with sufficient force to displace the presumption against extra-territorial application' of US law. ${ }^{291}$ This has significant implications for victims of forced labour within the global supply chains of US-domiciled MNCs. Courts have since taken a mixed approach to cases involving US defendants and harms occurring outside the US. ${ }^{292}$ The general consensus seems to be that some conduct relevant to the harm must take place on US territory and mere incorporation in the US is insufficient. ${ }^{293}$ Ultimately, Kiobel makes it unlikely the ATS will be used for abuses that occur outside the US. ${ }^{294}$ For example, Kiobel was recently used to dismiss a case against KBR concerning forced labour at a US military facility in Iraq. ${ }^{295}$

Civil claims provide an effective form of monetary redress for victims where they are successful or result in settlements. ${ }^{296}$ However, the chances of successful civil claims against MNCs by the employees of suppliers abroad remain low. There are still significant practical

\footnotetext{
${ }^{284}$ Licea v Curacao Drydock Company, Inc, 584 F.Supp.2d 1355 (S.D. Fla. 2008).

${ }^{285}$ Baughen (n 264) 46-47.

${ }^{286}$ See case for: Romero v Drummond Co, Inc, 552 F.3d 1303 (11th Cir. 2008); Case against: Kiobel v Royal Dutch Petroleum Co, 621 F.3d 111 (2d Cir. 2010).

${ }^{287}$ Doe v Unocal (n 335); Adhikari, et al v Daoud \& Partners, et al, 697 F.Supp.2d 674 (S.D. Tex. 2009).

${ }^{288}$ John Roe I v Bridgestone Corp, 492 F.Supp.2d 988 (S.D. Ind. 2007); Note this aspect of the case has been reversed by Judge Posner in Flomo et al v Firestone Natural Rubber Co, No. 10-03675 (7th Cir. 2011).

${ }^{289}$ Kiobel v Royal Dutch Petroleum Co, 133 S. Ct. 1659 (2013).

${ }^{290}$ Baughen (n 264) 47.

${ }^{291}$ Kiobel (n 289) 14.

${ }^{292}$ Eg failure in Balintulo v Daimler AG, No. 09-2778 (2nd Cir. 2013); success in Sexual Minorities Uganda v Lively 960 F.Supp.2d 304 (C.D. Mass. 2013).

${ }^{293}$ Baughen (n 264) 104-108.

${ }^{294}$ Forum non conveniens is another hurdle in this context.

${ }^{295}$ Mehra and Shay (n 83) 465.

${ }^{296}$ Meeran (n 126) 379.
} 
and legal obstacles to holding corporations liable for forced labour occurring within their global supply chains. This may stem from the fact that MNCs are not generally legally obliged to respect human rights. ${ }^{297}$ Civil actions can, however, provide a way of holding corporations more fully to account for the claims they make in their codes of conduct. ${ }^{298}$ While some argue that this might discourage MNCs from establishing voluntary codes of conduct and exercising due diligence, as we have seen this overlooks the societal and market pressures on MNCs to respect human rights. ${ }^{299}$ Indeed, it is arguable that the threat of litigation can put pressure on corporations fearful of legal liability and bad publicity, deterring them from engaging in forced labour and incentivising them to exercise due diligence. ${ }^{300}$ Unsurprisingly, many scholars argue that tort law should be expanded to reflect the economic 'realities of global production' and to prevent corporations from structuring their activities to avoid liability. ${ }^{301}$ Extending corporate liability to encompass forced labour within global supply chains would not necessarily open the 'floodgates' to an indeterminate number of claims but would create financial and other reasons for corporations to exercise due diligence and to abide by their own stated codes of conduct. ${ }^{302}$

\section{CONCLUSION}

The scale and severity of forced labour makes it one of the most challenging human rights issues facing the world today. Its transnational and multi-dimensional nature means that to tackle it, concerted efforts that target its multifarious dimensions are required by both states and corporations. States are territorially and jurisdictionally limited, but MNCs are wellpositioned to monitor and influence their supply chains. The three pillars in the UNGPs offer much potential, individually and collectively, to tackle forced labour. The biggest challenge lies in implementation. Measures to tackle forced labour that amount to implementation of the UNGPs utilize market, societal and legal forces to varying degrees in order to encourage MNCs to exercise due diligence. Although these are promising developments, these measures suffer from a number of shortcomings that derive from the unique challenges forced labour poses as well as the inherent limitations of the measures themselves. There is no clear solution to these problems, but a multi-pronged approach is certainly required, striking the

\footnotetext{
${ }^{297}$ McCorquodale (n 40) 394.

${ }^{298}$ Conway (n 270) 783.

299 ibid 780.

${ }^{300}$ George and Smith (n 74) 91.

${ }^{301}$ Conway (n 270) 784.

302 ibid 779-782.
} 
right balance between mutually reinforcing voluntary and mandatory measures that incentivise MNCs to address forced labour.

All articles published in the UCL Journal of Law and Jurisprudence are licensed under the Creative Commons Attribution License (CC-BY) 4.0 international license agreement and published open access, making them immediately and freely available to read and download. The CC-BY license agreement allows authors to retain copyright while allowing others to copy, distribute, and make some uses of the work. Further information regarding this can be found athttps://creativecommons.org/licenses/by/4.0/. 